Etnográfica

Revista do Centro em Rede de Investigação em

Antropologia

vol. $18(2) \mid 2014$

Vol. $18(2)$

\title{
Working the boundaries: anthropology and multidisciplinarity in Canada
}

Trabalhar as fronteiras: antropologia e multidisciplinaridade no Canadá

\section{Noel Dyck}

\section{(2) OpenEdition}

\section{Journals}

Electronic version

URL: https://journals.openedition.org/etnografica/3665

DOI: 10.4000/etnografica.3665

ISSN: 2182-2891

\section{Publisher}

Centro em Rede de Investigação em Antropologia

\section{Printed version}

Date of publication: 1 June 2014

Number of pages: $255-273$

ISSN: 0873-6561

\section{Electronic reference}

Noel Dyck, "Working the boundaries: anthropology and multidisciplinarity in Canada", Etnográfica

[Online], vol. 18 (2) | 2014, Online since 09 July 2014, connection on 09 February 2022. URL: http:// journals.openedition.org/etnografica/3665 ; DOI: https://doi.org/10.4000/etnografica.3665

\section{(c) (i) (8)}

Etnográfica is licensed under a Creative Commons Attribution-NonCommercial 4.0 International License. 


\section{Working the boundaries: anthropology and multidisciplinarity in Canada}

Noel Dyck

The pronounced governmental and administrative endorsement in Canada of interdisciplinary and collaborative research raises questions about the purposes and impacts of these approaches upon a discipline such as anthropology. Although Canadian anthropology has a lengthy history of involvement in extradisciplinary undertakings, the conditions that have enabled such voluntary collaborations are being rapidly replaced by a quite different set of arrangements and prescriptions. This paper examines the implications of working within and across disciplinary boundaries in contemporary Canadian anthropology, making particular reference to the field of Aboriginal studies and to the study of sport and childhood. It is argued that the most effective means to defend anthropology against the marginalization threatened by current developments is to rigorously distinguish multi- from inter-disciplinarity and to embrace the former as a means that both permits and requires continuing articulation of anthropology's distinctive practices and objectives.

KEYWORDS: interdisciplinarity, multidisciplinarity, neoliberalism, Aboriginality, sport, childhood.

Trabalhar as fronteiras: antropologia e multidisciplinaridade no Canadá A interdisciplinaridade e a investigação colaborativa são fortemente valorizadas pelas entidades governamentais e administrativas no Canadá, o que levanta questões sobre os objetivos e efeitos de tais opções numa disciplina como a antropologia. Embora a antropologia canadiana tenha uma longa história de envolvimento em ações extradisciplinares, as condições que permitiram essas colaborações voluntárias estão a ser rapidamente substituídas por um conjunto bem diferente de normas e orientações. $\mathrm{O}$ artigo analisa as implicações do trabalho no interior das fronteiras disciplinares e para além delas na antropologia canadiana contemporânea, com referência especialmente aos campos dos estudos aborígenes e dos estudos sobre desporto e infância. $\mathrm{O}$ autor defende que a maneira mais eficaz de defender a antropologia contra o risco de marginalização ditado pela situação atual será distinguir rigorosamente a multidisciplinaridade da interdisciplinaridade e apostar na primeira, como meio que simultaneamente permite e requer a continuidade da articulação das práticas e objetivos próprios da antropologia.

PALAVRAS-CHAVE: interdisciplinaridade, multidisciplinaridade, neoliberalismo, indigenismo, desporto, infância.

DYCK, Noel (ndyck@sfu.ca) - Department of Sociology and Anthropology, Simon Fraser University, Canada. 
IN CANADA EXTRADISCIPLINARY ACADEMIC RESEARCH COLLABORATION has recently moved from being regarded as an option that may sometimes prove useful to become instead an institutionally preferred way of envisioning research in general. This message is articulated through an official discourse of interdisciplinarity that figures prominently within the listed priorities of Canadian universities and granting agencies. In consequence, administrative commitments to networking and extradisciplinary collaboration are being proclaimed as if neither of these had ever been contemplated, let alone engaged in, by Canadian academics. ${ }^{1}$ In fact, collaboration and cooperation by anthropologists and practitioners of other disciplines, as well as between anthropologists and non-academic groups, has, when deemed to be mutually beneficial, occurred informally and voluntarily over many decades. But previous practice of these approaches seems not to interest those appointed to reformulate policies for publicly funded knowledge creation and dissemination in accordance with neoliberal objectives. The mandate to create and manage "innovation" appears to involve viewing pre-existing modes of scholarship with scepticism, if not outright ignoring them.

This paper examines some aspects of the resulting politics of interdisciplinarity, which are front and centre within the institutional arrangements that anthropologists are now obliged to deal with when organizing their research and teaching. In light of the previous involvement of Canadian anthropologists in multidisciplinary and collaborative research undertakings, one might have anticipated that they would thrive within this new regime of knowledge creation. But the conditions in which anthropologists have worked productively with non-anthropologists in years gone by are not, in certain vital respects, the same as those now in effect. Hence, the importance of charting anthropologists' experiences with this unfolding initiative, which I will address here with reference to specific fields of research in which I have been involved as an active participant.

Beginning in the late 1960s, I spent several decades examining relations between Aboriginal peoples and governments in Canada, a field of study that was initially shaped in large part by anthropological approaches. But as Aboriginal-state relationships became a national political issue, academic researchers in political science, public policy, business studies, as well as First Nations studies programs began to enter this field, thereby transforming it into a multidisciplinary domain. A second field in which I have conducted research focuses upon the use of sport as an auxiliary mode of child rearing by middle- and upper-middle-class families in Canada. Since these intertwined

1 This was, indeed, one of the key and much-heralded outcomes of a "transformational" review exercise conducted in 2004-2005 by the Social Sciences and Humanities Research Council of Canada (SSHRC), the main funding source relied upon by Canadian anthropologists. 
practices of sport and parenting unfold in arenas that anthropologists have only recently begun to study, doing so has involved frequent encounters with methodological and analytical approaches preferred within other disciplines. Examining children's sport has also involved coming to terms with the diverging interests of parents, sport organizations, and government agencies, not to mention those of child athletes. These varying types of collaboration within and beyond the academy provide an empirical basis for illuminating some of the impacts of managerially required regimes of interdisciplinarity upon contemporary anthropological scholarship.

The paper does not endeavour to formulate an abstract model of either the potential benefits and/or disadvantages of transdisciplinary collaboration or the practice of interdisciplinarity per se. Instead, it offers a grounded account of some of the ways in which the practice of anthropology in Canada is being reshaped by an administrative initiative designed ostensibly to implement "innovation" within fields of knowledge creation that are being harnessed to meet new priorities.

\section{FROM OPEN MINDS TO OPEN SYSTEMS}

Contrary to the suppositions that underpin current injunctions to academics to work across the boundaries of their disciplines, this is not a new development within anthropology. It was, indeed, one of the considerations that initially attracted me to this discipline. Prior to commencing doctoral studies in social anthropology at the University of Manchester, I had completed an undergraduate degree in history and then an archive-based postgraduate thesis that examined the immediate consequences for Aboriginal peoples and the Canadian state of the sudden disappearance of the buffalo from the Canadian prairies in the late 1870 s. This project had, among other things, raised what seemed to me an intriguing possibility: specifically, what if I were able to extend my study of Aboriginal-state relations into the present day by gathering the contemporary equivalents of the types of information found in $19^{\text {th }}$ century institutional records without having to wait until these were one day archived and made accessible to researchers? Better yet, what if I were able to ask present-day Aboriginal leaders and government officials the sorts of questions that had occurred to me while analysing archival sources, but about which the historical documents had often remained frustratingly silent? And so I set off for Manchester and anthropology, reasoning that this would equip me to become, as I then envisioned it, a sort of ethnographer-cum-historian of the present.

The department in which I landed provided a stimulating home for a disciplinary migrant: most members of staff and a good many of my fellow students had similarly shifted into social anthropology at the postgraduate level. What 
was more, the Manchester Seminar had some years earlier tackled the nature of disciplinary boundaries, as well as arguments for and against transgressing them. These matters were explored in Closed Systems and Open Minds: the Limits of Nä̈vety in Social Anthropology, edited by Max Gluckman (1964). Contributors to that volume recounted how they addressed the essential tasks of formulating and limiting their fields of inquiry. ${ }^{2}$ Moreover, they discussed whether, and, if so, how, anthropologists might be permitted to employ "naïve" - naïve by virtue of being "non-expert" - understandings of phenomena observed and theories advanced by other scientific disciplines that shared an interest in their chosen fields. What each anthropologist needed to determine, the contributors agreed, was how best to "close" or restrict his or her analytical field while remaining aware that doing so might well lead to the exclusion of significant events and relations between such events (Devons and Gluckman 1964a: 185).

Achieving a judicious balance between "closed systems" and "open minds" was not, however, a simple matter. On the one hand, Gluckman contended that social anthropologists were not merely justified in making naïve assumptions when looking beyond the boundaries of their own discipline, but, indeed, virtually had a duty to do so, even if this might limit the conclusions that could be drawn from their analyses (Devons and Gluckman 1964b: v-vi). On the other hand, although he and Devons acknowledged that a social scientist could profit from reading disciplines other than his or her own, they warned that it is "dangerous to practise them without training and appropriate skills" (Devons and Gluckman 1964a: 261). Allowing that the analysis of complex problems might well require the collaboration of scientists from several disciplines, they nonetheless cautioned that "this does not dispose of the necessity for each to delimit his own field of study, and to work with techniques, data, and concepts appropriate to the analysis of that field" (Devons and Gluckman 1964c: 18).

In effect, this amounted to a call for multidisciplinary undertakings that would not privilege any single mode of disciplinary practice but would treat all as being complementary to one another. Combining results and insights from disciplinarily distinctive approaches would, they concluded, comprise another set of challenging problems. No less complicated would be the business of determining how to apply understandings thus gained to "the practical

2 I am indebted to one of the anonymous assessors of this article for noting that Gluckman, the first Professor of Social Anthropology at the University of Manchester, and Devons, the Professor of Applied Economics, had initially been part of an administrative initiative to open up the social sciences at Manchester. The assessor further suggests: "Subsequently I think he [Gluckman] realized what that meant for Anthropology (i.e. potential marginalization) and so would suggest that this might shape his call for naïvety. Interdisciplinarity (like disciplinarity) always comes with institutional politics. Was his warning about the dangers of uninformed interdisciplinary wanderings an attempt to patrol disciplinary terrain?" 
problems of dealing with social issues and policies" (Devons and Gluckman 1964c: 19).

By the 1960s, then, the implications of working within and across disciplinary boundaries had been recognized as matters of anthropological concern both in Manchester and beyond. During the next three decades, however, this initiative - along with other instances of autonomous intellectual examinations of and experimentation with collaboration and interdisciplinarity - was submerged beneath the waves created by the wholesale application of neoliberal principles and practices within the post-secondary education sector.

\section{NEW WAVE INTERDISCIPLINARITY}

The appropriation and rebranding of interdisciplinarity and collaboration as preferred practices and key symbols of $2 \mathrm{I}^{\text {st }}$ century universities has been part of the implementation of a larger neoliberal blueprint for publicly funded institutions. These developments, as Shore (2010) notes, reflect "a wider paradigm shift from the idea of tertiary education as a 'public good' geared to producing an educated citizenry to a conception of higher education as an individual economic investment" (Shore 2010: 15). This in turn has launched "a new vision of universities as transnational business corporations operating in a competitive 'global knowledge economy'" (Shore 2010: 15). In essence, neoliberal forms of governance "seek to manage public activities by finding proxies for market mechanisms. The market is held to guarantee 'efficiency', while the distribution of public funds is argued to have no equivalent mechanism" (Holmwood 2010: 640-641). So while markets, private companies, and "for profit" activities are increasingly "freed" from being objects of public policy, there has been an offsetting expansion in the regulation of publicly-funded institutions in an attempt to make these mimic the functioning of the "private sector" (Holmwood 2010: 641).

The drive to corporatize universities in Canada and elsewhere has entailed the use of a range of measures, including: private funding of research; "strategic partnerships" between universities and industries; corporate sponsorship of scholarships and research chairs; and, the development of technology transfer arrangements and patent development offices in universities (Hearn 2003: 8-9). This has been facilitated by a fundamental restructuring of the governance of universities, a development that has inflated the numbers, powers, and salaries of university administrators. Not surprisingly, the "orderly" creation, distribution, and application of knowledge are more and more treated as institutional undertakings that must be actively managed by professional administrators "in the public interest." This approach accentuates the hierarchical and bureaucratic nature of these institutions and contributes to the de-professionalization and proletarianization of academic work (Shore 2010:27). 
Insistence upon the adoption of administrative measures that are said to promote "efficiency" and "accountability" within universities has been accompanied by an emerging tendency on the part of administrators to express doubt about the capacities and appropriateness of previously developed forms of academic practice. Disciplinarity, therefore, tends to be referred to by "knowledge managers" in terms of its alleged tendencies to indulge shortsightedness and partiality. This unsympathetic depiction of disciplinarity is juxtaposed to idealized versions of interdisciplinarity, which are celebrated as being eminently suited to the complexities and needs of the contemporary world by virtue of their responsiveness to the need for "pluralism, shared values, collaboration, and public involvement" (Strathern 2005: 82). This stylized contrasting of disciplinarity and interdisciplinarity relies upon obfuscation of what Hearn (2003) distinguishes as conceptual and instrumental treatments of interdisciplinarity. The former is primarily intellectual in nature and purpose and pertains to "the practice of interdisciplinarity as scholarly activity in and of itself" (Hearn 2003: 2), while the latter "takes its impetus and instructions from beyond the walls of the academy, from the "real" world of industry and government" (Hearn 2003: 2).

Engagement with intellectual or "conceptual" assessments of the advantages and limitations of both disciplinary and interdisciplinary approaches stretches back to the beginnings of modern academic disciplines and will no doubt continue into the future. Paradoxically, in their efforts to transcend the perceived restrictions posed by disciplinary boundaries, supporters of one or another initiative to achieve interdisciplinarity in effect render the edges or boundaries of disciplinary knowledge essential to their own inquiries. In this respect, disciplinarity and interdisciplinarity co-constitute one another (Angus 2011) and "preserve the idea of conflict and debate embedded as a core value of the university" (Hearn 2003: 12). The Manchester School's interrogation was a relatively early anthropological assessment of the nexus between these two approaches. More recent ones include those by Strathern (2005), Rockhill (2007), Whimp (2008), Poblocki (2009), Shore (2010), Corin (2012), Suchman (2013), and Strathern and Rockhill (2013).

The type of instrumental interdisciplinarity introduced into Canadian universities in recent years embodies something of a different order. Hearn (2003) questions the role it has played in the corporatization of universities in Canada:

"Has instrumental interdisciplinarity served to legitimate and indeed bolster the interests of private corporate interests on campus? Problem-focused, or instrumental, interdisciplinary research is particularly vulnerable to the external logic of corporate interests as it can leave unexamined the assumptions behind the delineation of 'problems' to be studied, the sources 
of its funding, and the social, political and economic implications of the 'solutions' it offers. Here, we can see how the rubric of 'interdisciplinarity' serves as a kind of Trojan horse, smuggling external political and economic interests inside the walls of the academy. And so 'interdisciplinarity' becomes a sign or code word. Cloaked in the rhetoric of academic freedom and innovation, 'interdisciplinarity' can serve as a rationale and a source of legitimation for private interests and corporate-style institutional arrangements inside the academy. Academic administrators love to feel as though they are on the cutting edge. The use of the term 'interdisciplinarity' in grant applications and funding proposals works to assure them they are. With this term, they are able to signal one meaning - free academic innovation in knowledge formation - and execute another - an uncritical capitulation to agendas and problems determined by government and corporate interests" (Hearn 2003: 9).

Strathern (2005) and Rockhill (2007) have traced the interplay of management practices and forms of academic research in a government-funded genetic knowledge park established and operated in England for five years. Although required by the funding organizations to be multidisciplinary in form, the initial proposal for this particular undertaking went beyond this to commit to achieving "partnership" and "interdisciplinarity" (Rockhill 2007: 125-126). While multidisciplinarity entails bringing together practitioners of different disciplines, each of whom will employ their own disciplinary methods to work on a common problem, interdisciplinarity aims to integrate modes of investigation and thinking from two or more disciplines. As Rockhill notes, "interdisciplinary work is described as 'full' or 'partial,' depending upon the degree of interaction, collaboration, and integration" (Rockhill 2007: 126) that is exhibited within a research network or team. Yet, as Strathern points out, opting to include practitioners from different disciplines is one thing, while demonstrating the extent of actual integration is quite another:

"The evidence for such integration must lie in the testimony of those involved, that they had learned things that they had not done before, that their working practices registered an alteration as a consequence of interaction with others. And that they were prepared to describe them that way. I do not see how we can bypass the fact that we would need to be told. As soon as one introduces the issue of description, however, one encounters representation" (Strathern 2005: 85, italics in the original).

Accordingly, establishing the extent to which interdisciplinary undertakings might actually achieve methodological and epistemological "integration" relies upon how outcomes are testified to or "performed". In the case of this 
particular genetic knowledge park, the design of which was not academic, the epistemologies of the disciplines engaged within it were not in the end reshaped into a single framework:

"There was no conscious effort to create the kind of recursive, iterative relations that would identify a discipline or an epistemic community in which, in the process of sharing ideas, people had to constantly check back with what others were doing or look for confirmation that they were on the right track or seek out criticism of their efforts. This happened neither in the course of day-to-day existence nor in the generation of intellectual or conceptual work. With this absence of the epistemic community, those with an academic background found it necessary to refer back to their disciplinary communities located elsewhere" (Rockhill 2007: 129-130).

The intellectual demands awaiting the quest for conceptual interdisciplinarity in this instance were no less formidable than Gluckman had predicted these would be. But outcomes of this sort do not seem to diminish the lure of arguably instrumental declarations of interdisciplinarity by those who are keen to act as key "players" or "partners" in contemporary university research undertakings. In light of the pace of this rapidly advancing orthodoxy, it seems worth asking whether productive forms of anthropological collaboration with practitioners of other disciplines or with non-academic groups might be attainable short of subscribing unconditionally to current doctrines of interdisciplinarity. Past practices in anthropology offer some perspective on these matters.

\section{ANTHROPOLOGY AND THE STUDY OF ABORIGINAL-STATE RELATIONS}

Aboriginal peoples' dealings with imperial, colonial, and settler states in North America began long before the arrival of anthropology as an intellectual discipline. Anthropological studies of indigenous cultures and peoples have, therefore, always been conducted within contexts shaped by evolving regimes of Aboriginal-state relations (Dyck 2006). Until the $20^{\text {th }}$ century the administration of Indian affairs embodied one of the principal concerns of governments in Canada. Today the federal Department of Aboriginal Affairs and Northern Development still administers the Indian Act (a federal statute) and participates in a relationship that reaches back to colonial times. To acknowledge this is to raise the matter of how anthropologists in different eras have taken account of the shifting political dealings and institutional arrangements between Aboriginal peoples and governments. From the $19^{\text {th }}$ century to the middle third of the $20^{\text {th }}$ century, anthropology and Indian administration tended to be envisioned by their respective practitioners as quite separate fields of endeavour, despite their common focus on Aboriginal peoples. 
Anthropological works from this period rarely made even passing reference to the on-going administration of Indian affairs in Canada: this was not seen to be part of the discipline's proper concerns.

During the middle third of the $20^{\text {th }}$ century, however, the consequences of a second world war followed by large-scale international decolonization, raised questions about previously taken-for-granted aspects of the Canadian state's administration of Aboriginal peoples. For their part anthropologists began to look beyond their traditional disciplinary preoccupation with "salvage" ethnography and pre-contact ethnological reconstructions to take note of racism and the denial of rights of citizenship to Aboriginal peoples. Grappling with these matters obliged anthropologists to take notice of state administration of Aboriginal peoples. One of the first anthropological studies to do so was Tribe Under Trust (Hanks and Hanks 1950), an innovative work that presented an extended case study of the Canadian state's administration of the Blackfoot Reserve in Alberta. As well as tracing the setting up of this reserve as a legal and geographical entity, it detailed the sale of portions of reserve lands, the establishment of trust funds, and the repercussions of these and other administrative measures on reserve life. Elucidating the ways in which federal administration had fostered class divisions within the reserve population, Hanks and Hanks shifted the ethnographic focus from the search for "untouched" aspects of "original" Aboriginal cultures to the complexities and unfolding consequences of Aboriginal-state relations. Dunning's Social and Economic Change among the Northern Ojibwa (1959) reinforced this reordering of priorities by examining the reverberations of post-war welfare state programs and provisions upon Ojibwa marriage patterns, kinship organization, and political authority.

In the 1960s this realignment of anthropological interests was reinforced when two well-known Canadian anthropologists, Harry Hawthorn and Marc-Adélard Tremblay, were invited by federal officials to conduct a national survey of Canadian Indians. This first-ever social science review of First Nations living conditions was commissioned to provide a bureaucratically usable study at a time when growing doubt was surfacing about the appropriateness of federal administration of Aboriginal peoples (Dyck 2006: 82). Hawthorn and Tremblay, along with their multidisciplinary team of researchers, spent several years conducting original research - much of it ethnographic - and preparing a two-volume, published report (Hawthorn et al., 1966, 1967). ${ }^{3}$ It featured jargon-free language, detailed qualitative and quantitative studies, and a set

3 The striking of a multidisciplinary study of the situation of Canadian Indians was less a matter of balancing disciplinary perspectives than of enlisting the assistance of the relatively small number of Canadian academics who at that time possessed any interest in and experience of examining issues pertaining to Aboriginal peoples in Canada. 
of recommendations that rested within the powers of the federal government to implement (Weaver 1993: 79-80). In addition to observing the terms of their commission, they demonstrated the capacities of ethnographic research to contribute to public policy analysis. Confronted by the complexities and contradictions of Canada's relationship with its Aboriginal peoples, the federal government arbitrarily and quite unexpectedly declared its intention to terminate its involvement in the administration of Indian affairs, a measure that had neither been requested by Aboriginal leaders nor recommended in the Hawthorn-Tremblay Report. This announcement sparked an unprecedented national controversy that a year later forced the federal government to retract its proposals. The notion of Aboriginal peoples as "citizens plus" that had been developed in the Hawthorn-Tremblay Report became a key part of the position established by a new generation of Aboriginal leaders.

Thus, in the space of a decade Aboriginal-state relations had been redefined as a leading political issue. The upshot for Canadian anthropology of the involvement of a growing number of its practitioners with this issue was profound. A set of empirically grounded and theoretically provocative ethnographies of Aboriginal peoples' diverse dealings with governments emerged in the following decades (Brody 1971, 1981; Culhane Speck 1987; Dyck 1983, 1991, 1997; Dyck and Waldram 1993; Feit 1989; Henriksen 1973; La Rusic 1979; Lithman 1984; Paine 1977; Ryan 1978; Salisbury 1986; Scott 1989; Tanner 1983; Waldram 1988; Weaver 1981). Moreover, anthropologists began to compare the form and nature of Aboriginal-state relations in Canada with those in Norway and Australia (Dyck 1985). Anthropology's treatment of state administration of Aboriginal affairs had moved from a stance of principled avoidance to one of intensive intellectual and political engagement. Anthropological fieldworkers were often "conscripted" formally or informally by band and tribal council leaders to assist in the preparation of reports, proposals, or position papers on a range of policy matters. Some postgraduate students postponed completion of their studies in order to take paid positions with provincial, territorial, and national Aboriginal organizations. Those who opted to return to their studies tended to incorporate into their scholarly publications what they had learned in the course of their experiences as advocates (Dyck 2006: 85-86).

Anthropologists' pre-eminence within this field was, nonetheless, relatively short-lived. The achievements they had registered, along with the expansion of various forms of research funding for work in the field, did not go unnoticed. Court cases mounted in support of Aboriginal land claims as well as developments that connected Aboriginal peoples to the larger issues of national unity and constitutional reform assumed growing political importance and opened up new sources of research funding. Faculty members and graduate students from many disciplines - including political science, public policy, communications, 
history, and law - mounted research projects in this field and found ways to engage in consultancy work with Aboriginal organizations. Anthropologists with academic and practical experience in this field were frequently invited to join collaborative, interdisciplinary initiatives. But doing so often proved to be rather more challenging than might initially have been appreciated. Because the methodological approaches and analytical assumptions of anthropology did not always fit seamlessly with those of other disciplines, "ethnographers were pressured to bear more than their fair share of the costs of enabling interdisciplinary' inquiry" (Dyck 2006: 86).

The subsequent creation of Native studies programs in many Canadian universities unleashed highly charged questions, borrowed from the ascendant identity politics of the late $20^{\text {th }}$ century, concerning the propriety of non-Aboriginal researchers' involvement in ethnographic research on Aboriginal issues. ${ }^{4}$ By the end of the century the conditions facing ethnographers of Aboriginal issues and administration had fundamentally changed:

"The solipsistic critique of ethnography unleashed within anthropology by a generation of anthropologists eager to stake their claims to theoretical and ethical sophistication, whatever the consequences for their discipline, conspired for a time to make ethnographic endeavour of almost any kind seem a risible and even risky undertaking. The federal government's arbitrary imposition on academe of a nationwide regime of compulsory research ethics regulation that envisioned intellectual inquiry with human subjects almost solely in terms of biomedical models served to further discourage the practice of ethnography in general, and of ethnographic research into Aboriginal-state relations in particular. Under these circumstances it is hardly surprising that independent ethnographic inquiry into the evolving field of Indian administration came to be identified in some quarters as being 'problematic'” (Dyck 2006: 86-87).

Ethnographers responded to these changed conditions in different ways. Some "retired" from ethnographic research to mount historical studies or examinations of Aboriginal legal or policy issues that could be conducted primarily through the use of existing textual materials. Others endeavoured to pursue programs of community-based research in partnership with Aboriginal organizations under the rubric of applied anthropology. A few opted to combine teaching with paid consultancy, an arrangement that effectively permitted them to conduct undisclosed forms and amounts of ethnographic research

4 A number of anthropologists have contributed substantially to the development of native studies programs in Canadian universities. Anthropological works and approaches have been variously criticized and utilized at different times by scholars in this field. 
without having to submit these undertakings for institutional ethical review by their universities. Still others moved to take up ethnographic research projects in other fields. Regardless of the path selected by those involved in the study of Aboriginal-state relations, none could be said to be unaware of the possibilities for or implications of conducting interdisciplinary or collaborative research.

What also needs to be borne in mind is the manner in which Aboriginal-state relations have changed since the late 1960s to become not only matters of public policy but also a locus for major financial activity and engagement. The transfer of a wide range of administrative and service provision functions from the federal government to band and tribal authorities along with substantial amounts of funding has in turn enabled Aboriginal governments to purchase services from private consultants, service providers, and suppliers. Moreover, measures taken to facilitate the presentation and settlement of Aboriginal land claims have been accompanied by federal financial loans to Aboriginal authorities to underwrite the soaring costs of research, legal advice, and administrative services. Although determination by Canadian courts of the nature and extent of Aboriginal land rights continues to be contested both legally and politically, large-scale natural resource development projects in many parts of Canada are now in practice subject to being blocked or delayed until agreements are reached with Aboriginal communities whose land and resources are affected. All in all, there are now very substantial financial interests of both a short-term and long-term nature that hinge upon the collection and control of knowledge about the circumstances and organization of Aboriginal peoples and communities in Canada.

As the amounts of money at stake in Aboriginal-state-corporate relationships have grown, ethnographically-based inquiries within this field have increasingly been marginalized and abandoned. The political operatives and business consultants who control the greatest part of the research now done in this sector are not subject to the types of monitoring applied to anthropologists and other academic researchers. Nor are their careers based upon the expectation that they make their findings freely and readily available. The implementation of mandatory interdisciplinarity and collaboration cuts rather differently for these personnel than it does for academics, no matter how "inclusive" its rhetoric might sound to those who permit themselves to be naïve about such arrangements. The extension of neoliberal practices both with respect to the management of Aboriginal issues as well as to the supervision and control of academic inquiry into them appear to negate the likelihood of a latter-day repetition of anything like a free-ranging and potentially disruptive Hawthorn-Tremblay Commission. 


\section{ANTHROPOLOGY AND THE STUDY OF CHILDREN'S SPORTS}

What initially drew me to the study of children's sports were the similarities between the traditional rationale for Canada's system of state tutelage for Aboriginal peoples and the organizational discourse of community athletic activities in which my children had begun to participate. Federal Indian administration was founded on the premise that it would "save" its charges from the "burden" and stigma of their indigenous languages, cultures and practices (Dyck 1991, 2010: 161). Accordingly, the establishment in the late 19 ${ }^{\text {th }}$ and early $20^{\text {th }}$ centuries of Indian residential schools, which took girls and boys away from their parents and communities for years at a time, was undertaken to equip young Indians with supposedly civilized habits and beliefs that would allegedly facilitate their assimilation into Canadian society. As a parent, listening to the sometimes-extravagant claims made by coaches and community sport organizers about the capacities of sport to prepare young athletes to become highly successful adults, I was reminded of the roughly analogous assertions recited by generations of Indian administrators. That children's sports might also be underpinned by a regime of tutelage marked it as a topic for further investigation.

What seemed at the outset a fairly logical analytical progression - extending the examination of tutelage from its application within a system of state administration to ask how and why this mode of practice might figure in voluntary community sport activities for children and youths - proved to be a more complicated matter. From the outset, more than a few colleagues were perplexed by this shift in research focus. Moving from the study of Aboriginal-state relations to the dynamics of community sports in urban and suburban settings was read as retreating from the mainstream of the discipline to its outermost margins. And as if the prospect of an anthropologist looking into contemporary, western sports wasn't bad enough, focusing on what might be dismissed as "child's play" only compounded the damage, accelerating a spiralling descent from the anthropologically inappropriate to the utterly inconsequential. There was not, in short, an overabundance of anthropological interest in or support for the study of children's sport. Nor was there much in the way of published literature on this topic beyond that produced by physical educators for their own use. Nevertheless, one of the rewards of preparing a preliminary map of an underdeveloped or prospective field of study is that of identifying the work of other scholars who might be pursuing questions and concerns that touch upon or overlap to some extent with one's own.

The broader social science literature on sport includes works by historians, political scientists, and psychologists, but a particularly substantial contribution has come from sport sociologists. To read their publications and attend their conferences is to enter a congenial zone where no apology is made for 
taking sport seriously and investigating the myriad ways in which it is implicated in contemporary life. Moreover, some of those active in the sociology of sport began their academic training or professional careers as anthropologists before taking positions in programs or units that have been more welcoming of the study of sport than the vast majority of anthropology departments. Thus, anthropologists may adopt sociological approaches to sport that enable them to find a place for themselves within the emerging and nominally interdisciplinary - but in fact substantially sociological - field of "sport studies". Yet should they prefer to frame and pursue their studies in ways that although familiar to anthropologists do not always coincide with sociological preferences, they are likely to be met with challenges and criticisms that can become wearing. In order to continue investigating sport and writing about it from an anthropological perspective, it seems advisable to proclaim rather than to camouflage the nature of one's disciplinary point of departure. Subscribing explicitly and vocally to the tenets of multidisciplinarity likely offers anthropologists of sport more leeway than does wrapping themselves into knots to fit the ambit of one or another faux version of interdisciplinarity.

Of course, sport represents just one of the fields that might be expected to figure within the study of children's sport. The other, the study of childhood, has in recent decades emerged from being controlled primarily by psychologists and educators to become a vibrant and expanding field of transdisciplinary inquiry. Anthropologists have made key contributions to childhood studies both within and beyond their discipline by illuminating the varying ways in which childhood has been constructed across space and time. In consequence, comparative and ethnographic approaches enjoy relatively wide acceptance within this field. Recognition of the political dimensions of relations between children, parents, social institutions, and states makes it possible to link childhood studies ethnographically and conceptually to, for instance, the study of Aboriginal-state relations. What remains to be seen, however, is whether the popularity and institutional growth of childhood studies might result in concentrating the study of children and childhood within an increasingly specialized and, potentially, ghettoized sector.

While invocation of the ideals of interdisciplinarity raises expectations of intellectual openness and flexibility, a state of affairs that surely ought to appeal to all intellectuals, this can disguise more obdurate features of its actual practice. As Strathern (2005) has noted, the extent to which the principle of interdisciplinarity is attained in any given undertaking or field depends upon the persuasiveness of testimony to this effect by those involved. But the de facto boundaries of a "new" mode of practice implanted under the banner of interdisciplinarity may not in actuality be subject to modification. What may or may not be deemed to be appropriate methods, relevant literatures, preferred theorists, or acceptable purposes may be stolidly but uncompromisingly 
enforced in the name of interdisciplinarity. This general point comes into sharper focus when we look into more specific areas of research, especially those where researchers from smaller disciplines find themselves working between emerging academic fields whose practitioners are quick to defend the territories that have recently been occupied.

Since both childhood studies and sport studies are attuned to current mantras that enjoin academics to work beyond the boundaries of disciplinary practice, it is interesting to note just how little attention is paid by those engaged in each of these new fields to work being conducted in the other. Depictions of children and of childhood that bob up from time to time within the sports studies literature take scant account of analytical advances registered within the field of childhood studies. Within sport studies, conventional developmental psychology and socialization studies are still deferred to as the authoritative sources on all matters pertaining to children. By the same token, the burgeoning literatures of child and youth studies rarely offer more than passing mention of children's engagements with sport. Play might be categorized as a definitive feature of childhood, but sport tends to be treated more ambivalently, fostering the impression that the upshot of extensive and intensive participation in sport by some children and youths can be either ignored or taken for granted. This places ethnographers who believe not only that it is worth charting the dynamics and outcomes of children's sports but also that doing so requires the articulation of insights from each of these fields in a tricky situation. They are obliged to take cognizance of agendas and approaches developed within each of these fields without being seen to neglect or slight the priorities of either. Given that the fate of proposed panels for academic conferences, applications for research funding, and manuscripts submitted to journals and publishers depends upon the vagaries of assessor selection, pursuing ethnographic research within an ostensibly interdisciplinary field such as children's sports can prove to be a risky enterprise.

But these seemingly quotidian academic concerns need to be located within a wider context. On the one hand, social scientists that seek to construct holistic accounts of children's sports are increasingly being exposed to the risk of "collateral damage" by working between two notionally interdisciplinary fields. On the other, governments at all levels as well as businesses and corporate foundations are energetically staking out their respective claims to marshal and commoditize athletic activities for boys and girls. As it happens, anthropologists have examined some examples of these developments. For instance, Anderson (2008) details the complicated roles performed by children's sports in municipal leisure service provision as well as in national cultural policies in Denmark. Similarly, Dyck (2012) traces the manner in which the management of community sport for children in Canada is being co-opted by government initiatives and entrepreneurial philanthropy that aims to privatize this 
traditionally volunteer, non-profit sector. Clearly, children's sport is becoming a lucrative and crowded sector in a number of senses.

But how much longer, one might ask, will opportunities remain for anthropologists to propose and conduct ethnographic studies that might conceivably be labelled as "problematic", "incomplete", or "too narrow" either by academic competitors or non-academic organizations that insist upon their right to be recognized and consulted as "stakeholders" in the issues to be investigated? The practical implications of procedurally required interdisciplinarity and extradisciplinary collaboration may prove to be rather less beneficent than anthropologists might have imagined.

\section{CONCLUSIONS}

A small and politically marginal social science like anthropology cannot afford to be naïve about the ways in which it may be imperilled by contemporary institutional initiatives for interdisciplinarity and collaboration. The particular examples considered here are, of course, drawn in large part from Canada and may not, therefore, be equally pertinent to the circumstances of anthropologists elsewhere. Suffice it to say that readers will recognize which of the practices and problems reported here resemble those found within the settings they know best. Bearing this caveat in mind, I argue that if anthropologists do not take steps to safeguard the practice and integrity of their discipline, then either or both of these may potentially be effaced within the emerging academic order. Anthropologists can no longer afford to deal with interdisciplinarity as though it represents merely a neutral or disinterested opportunity for contemplative reflexivity and innovation. It can, indeed, sometimes serve as a Trojan horse.

Anthropologists alone are not going to reverse or vanquish neoliberalism within the academy. Therefore, the continued provision of opportunities and resources that permit the practice of anthropology depends upon our ability to articulate what it is we do and why it is important to our universities and societies that we continue to do it. To the extent that in today's circumstances interdisciplinarity can on occasion entail not so much a noble quest to transcend the limitations of disciplinary boundaries as an administrative ploy to promote what may amount to a disciplinary knock-out competition that pursues the neoliberal ideal of "flexibility," we ought not to play this game. Instead, we need to articulate reasoned, principled, but blunt critiques of the inherent contradictions bound up with administratively routinized forms of faux interdisciplinarity. The insights provided by Gluckman, Strathern, and others can be put to good use in framing these arguments.

What we need to promote is the practice of multidisciplinarity, a less radical but more plausible mode of intellectual collaboration that does not take 
as its starting point an alleged need to distrust and bypass the disciplined approaches to learning that intellectuals have developed over time and continue to develop. When practitioners of different disciplines choose to work together to examine various problems or questions, each of them bringing to this collaboration their own disciplinary insights, methods, and perspectives, they cannot help but take note of similarities and differences between their respective forms of practice. Whether and to what extent the pooling of their respective insights into a particular problem or question represents a step forward or a frustrating waste of time is a matter to be determined when all the results are in. Anthropologists should join with other academics to acknowledge the advantages of examining what lies beyond a discipline's current working boundaries. But this should not be confused with what is taking place, at least in Canada, under the guise of "innovation," "inclusion," and "interdisciplinarity."

\section{REFERENCES}

Anderson, Sally, 2008, Civil Sociality: Children, Sport, and Cultural Policy in Denmark. Charlotte, NC, Information Age Publishing.

ANGUS, Ian, 2011, "The telos of the good life: reflections on interdisciplinarity and models of knowledge", in Raphael Foshay (ed.), Valences of Interdisciplinarity: Theory, Practice, Pedagogy. Edmonton, AB, Athabasca University Press, 47-71.

BRODY, Hugh, 1971, Indians on Skid Row: The Role of Alcohol and Community in the Adaptive

Process of Indian Urban Migrants. Ottawa, Northern Science Research Group, Department of Indian Affairs and Northern Development (DIAND).

BRODY, Hugh, 1981, Maps and Dreams: Indians and the British Columbia Frontier. Vancouver: Douglas and McIntyre.

CORIN, Ellen, 2012, "Commentary: interdisciplinary dialogue: a site of estrangement", Ethos, 40 (1): 104-112.

CUlHANe SPECK, Dara, 1987, An Error in Judgement: The Politics of Medical Care in an Indian/White Community. Vancouver, Talonbooks.

DEVONS, Ely, and Max GLUCKMAN, 1964a, "Conclusion: modes and consequences of limiting a field of study", in Max Gluckman (ed.), Closed Systems and Open Minds: The Limits of Naïvety in Social Anthropology. Edinburgh and London, Oliver \& Boyd, 158-261.

DEVONS, Ely, and Max GLUCKMAN, 1964b, "Preface", in Max Gluckman (ed.), Closed Systems and Open Minds: The Limits of Naïvety in Social Anthropology. Edinburgh and London, Oliver \& Boyd, v-viii.

DEVONS, Ely, and Max GLUCKMAN, 1964c, "Introduction", in Max Gluckman (ed.), Closed Systems and Open Minds: The Limits of Naïvety in Social Anthropology. Edinburgh and London, Oliver \& Boyd, 13-19. 
DUNNING, Robert W., 1959, Social and Economic Change among the Northern Ojibwa. Toronto, University of Toronto Press.

DYCK, Noel, 1983, "Representation and leadership of a provincial Indian association”, in Adrian Tanner (ed.), The Politics of Indianness in Canadian Society. St. John's, Newfoundland, Institute of Social and Economic Research, Memorial University of Newfoundland, 197-305.

DYCK, Noel (ed.), 1985, Indigenous Peoples and the Nation-State: Fourth World Politics in Canada, Australia, and Norway. St. John's, Newfoundland, Institute of Social and Economic Research, Memorial University of Newfoundland.

DYCK, Noel, 1991, What Is the Indian 'Problem': Tutelage and Resistance in Canadian Indian Administration. St. John's, Newfoundland, Institute of Social and Economic Research, Memorial University of Newfoundland.

DYCK, Noel, 1997, Differing Visions: Administering Indian Residential Schooling in Prince Albert, 1867-1995. Halifax, Fernwood Publishing.

DYCK, Noel, 2006, "Canadian anthropology and the ethnography of 'Indian administration'”, in Julia Harrison and Regna Darnell (eds.), Historicizing Canadian Anthropology. Vancouver, Toronto, University of British Columbia Press, 78-92.

DYCK, Noel, 2010, "Remembering and the ethnography of children's sports", in Peter Collins and Anselma Gallinat (eds.), The Ethnographic Self as Resource: Writing Memory into Ethnography. New York and Oxford, Berghahn, 150-164.

DYCK, Noel, 2012, Fields of Play: An Ethnography of Children's Sports. Toronto, University of Toronto Press.

DYCK, Noel, and James B. WALDrAM (eds.), 1993, Anthropology, Public Policy and Native Peoples in Canada. Montreal and Kingston, McGill/Queen's University Press.

FEIT, Harvey A., 1989, "James Bay Cree self-governance and land management", in E. W. Wilmsen (ed.), We Are Here: Politics of Aboriginal Land Tenure. Berkeley, University of California Press, 68-98.

GLUCKMAN, Max (ed.), 1964, Closed Systems and Open Minds: The Limits of Nä̈vety in Social Anthropology. Edinburgh and London, Oliver \& Boyd.

HANKS, Lucien M., and Jane Richardson HANKS, 1950, Tribe Under Trust: A Study of the Blackfoot Reserve of Alberta. Toronto, University of Toronto Press.

HAWTHORN, Harry, et al., 1966, A Survey of the Contemporary Indians of Canada: Economic Political, and Educational Needs and Policies, vol. 1. Ottawa, Queen's Printer.

HAWTHORN, Harry, et al., 1967, A Survey of the Contemporary Indians of Canada: Economic Political, and Educational Needs and Policies, vol. 2. Ottawa, Queen's Printer.

HEARN, Alison, 2003, "Interdisciplinarity/extradisciplinarity: on the university and the active pursuit of knowledge", History of Intellectual Culture, 3 (1): 1-13, available at < http://www.ucalgary.ca/hic/issues/vol3/3> (last access 2014, May).

HENRIKSEN, Georg, 1973, Hunters in the Barrens: The Naskapi on the Edge of the Whiteman's World. St. John's, Newfoundland, Institute of Social and Economic Research, Memorial University of Newfoundland.

HOLMWOOD, John, 2010, "Sociology's misfortune: disciplines, interdisciplinarity and the impact of audit culture”, British Journal of Sociology, 61 (4): 639-658.

LA RUSIC, Ignatius E., et al., 1979, Negotiating a Way of Life: Initial Cree Experience with the Administrative Structure Arising from the James Bay Agreement. Ottawa, DIAND, Research Division. 
LITHMAN, Yngve Georg, 1984, The Community Apart: A Case Study of a Canadian Indian Reserve Community. Winnipeg, University of Manitoba Press.

PAINE, Robert (ed.), 1977, The White Arctic: Anthropological Essays on Tutelage and Ethnicity. St. John's, Newfoundland, Institute of Social and Economic Research, Memorial University of Newfoundland.

POBLOCKI, Kacper, 2009, "Whither anthropology without the nation-state? Interdisciplinarity, world anthropologies and commoditization of knowledge", Critique of Anthropology, 29 (2): 225-252.

ROCKHILL, Elena Khlinovskaya, 2007, "Of interdisciplinarity and models of knowledge production", Social Analysis, 51 (3): 121-147.

RYAN, Joan, 1978, Wall of Words: The Betrayal of the Urban Indian. Toronto, Peter Martin Associates.

SAlisbury, Richard F., 1986, A Homeland for the Cree: Regional Development in James Bay, 1971-1981. Kingston and Montreal, McGill/Queen's University Press.

SCOTT, Colin, 1989, "Ideology of reciprocity between the James Bay Cree and the whiteman state", in P. Skalnik (ed.), Outwitting the State. New Brunswick, USA, and London, Transaction Publishers, 89-108.

SHORE, Cris, 2010, "Beyond the multiversity: neoliberalism and the rise of the schizophrenic university", Social Anthropology, 18 (1): 15-29.

STRATHERN, Marilyn, 2005, "Experiments in interdisciplinarity", Social Anthropology, 13 (1): 75-90.

STRATHERN, Marilyn, and Elena Khlinovskaya ROCKHILL, 2013, "Unexpected consequences and an unanticipated outcome”, in Andrew Barry and Georgina Bone (eds.), Interdisciplinarity: Reconfigurations of the Social and Natural Sciences. Milton Park, UK, and New York, Routledge, 119-140.

SUCHMAN, Lucy, 2013, "Consuming anthropology", in Andrew Barry and Georgina Bone (eds.), Interdisciplinarity: Reconfigurations of the Social and Natural Sciences. Milton Park, UK, and New York, Routledge, 141-160.

TANNER, Adrian (ed.), 1983, The Politics of Indianness in Canadian Society. St. John's, Newfoundland, Institute of Social and Economic Research, Memorial University of Newfoundland.

WALDRAM, James B., 1988, As Long as the Rivers Run: Hydroelectric Development and Native Communities in Western Canada. Winnipeg, University of Manitoba Press.

WEAVER, Sally M., 1981, Making Canadian Indian Policy: The Hidden Agenda, 1968-1970. Toronto, University of Toronto Press.

WEAVER, Sally M., 1993, "The Hawthorn Report: Its use in the making of Canadian Indian policy”, in Noel Dyck and James W. Waldram (eds.), Anthropology, Public Policy and Native Peoples in Canada. Montreal and Kingston, McGill-Queens University Press, 75-97.

WHIMP, Graeme, 2008, "Interdisciplinarity and Pacific studies: roots and routes", The Contemporary Pacific, 20 (2): 397-421. 